\title{
Creative Mitigation: Alternative Strategies for Resources, Stakeholders, and the Public
}

\author{
John G. Douglass 0 and Shelby A. Manney
}

\section{ABSTRACT}

Standard mitigation treatment for adverse effects to significant cultural resources has historically been a combination of data recovery excavation along with artifact analysis, reporting, and curation, whose purpose is to move the undertaking forward. Over the past several decades, there has been increased interest and understanding of alternative, or creative, mitigation options in these situations, which may, in the end, be the best option for the resource and more meaningful to both project stakeholders and the public. This article, the first in this special issue on creative mitigation, introduces the regulatory and conceptual framework for creative mitigation and weaves themes introduced in subsequent articles in this issue.

Keywords: creative mitigation, alternative mitigation, National Historic Preservation Act, Section 106, regulations, stakeholders

El tratamiento de mitigación estándar para los efectos adversos a recursos culturales significativos ha sido históricamente una combinación de excavación de recuperación de datos junto con análisis de artefactos, informes y curación, con el resultado final de que la empresa puede avanzar. Durante la última década o más, ha aumentado el interés y la comprensión de las opciones de mitigación alternativas o creativas en estas situaciones que, al final, pueden ser la mejor opción para el recurso y más significativas para las partes interesadas del proyecto y el público. Este artículo, el documento introductorio en este número especial centrado en la mitigación creativa, presenta el marco regulatorio y conceptual para la mitigación creativa y teje los temas presentados en artículos posteriores en este número.

Palabras clave: mitigación creativa, mitigación alternativa, Ley Nacional de Preservación Histórica, Sección 106, regulaciones, partes interesades

In both the United States and abroad, the development of preservation laws and regulations has expanded the understanding of the past. Around the world, the practice of cultural resource management (CRM) and the associated regulatory environment have transformed the research fields of archaeology and historic preservation from explorations of the human past to mitigations of potential impacts to the human past (e.g., King 2013; O'Brien et al. 2005; Praetzellis and Praetzellis 2011; Raab et al. 1980). In the United States, CRM archaeologists work alongside local, state, federal, and tribal government officials to facilitate the implementation and execution of national and localized laws and regulations, including Section 106 of the National Historic Preservation Act (NHPA; NPS 2019) and the National Environmental Policy Act (NEPA). Although there are strong historic preservation laws in the United States, and in many places around the world, tensions remain about how to implement these laws in ways that are meaningful and relevant to tribal groups, descendant communities, the public, and other stakeholders of past places, such as archaeological sites.

The authors in this issue of Advances in Archaeological Practice, who study different avenues for undertaking creative mitigation, argue that the mitigation of adverse effects to archaeological sites needs to be meaningful to descendant communities and other stakeholders. All too often, the mechanical application of mitigation replaces meaningful and creative engagement with tribal communities and other descendant communities about the best ways to mitigate adverse effects to a significant resource (Bergman and Doershuk 2003:89).

Within the United States, a critical component of the NHPA is a federal agency's responsibility to determine the potential for a federal undertaking (see 36 Code of Federal Register [CFR] 800.16 [y]) to have an adverse effect on National Register of Historic Places (NRHP)-eligible cultural resources-that is, historic properties. It is an agency's responsibility to identify, treat, and mitigate for any immediate and cumulative effects the undertaking may have on eligible resources (NHPA 54 U.S.C. § 306108; implementing regulation 36 C.F.R part 800 ). Historically, the treatment of historic properties - in the case of this article, we are specifically thinking about archaeological sites and Traditional Cultural Properties (TCPs) - has tended to be a routine approach to historic preservation. These treatments are generally destructive and require partial or complete removal of the resources from their

Advances in Archaeological Practice 8(3), 2020, pp. 213-219

(1) The Author(s), 2020. Published by Cambridge University Press on behalf of Society for American Archaeology. This is an Open Access article, distributed under the terms of the Creative Commons Attribution licence (http://creativecommons.org/licenses/by/4.0/), which permits unrestricted re-use, distribution, and reproduction in any medium, provided the original work is properly cited.

DOI:10.1017/aap.2020.25 
original provenance. This treatment, referred to as "data recovery," satisfies the legal stipulations for mitigation of impacts of a federal undertaking to sensitive cultural resources (36 C.F.R., part 79). Data recovery is a baseline treatment for adverse effects to historic properties in the United States.

This introductory article sets the stage for the others in this issue by outlining how creative mitigation can augment both U.S. and international historic preservation regulations. Creative mitigation, as an alternative to more destructive and invasive practices, requires both critical thinking about the elements of the resource and consideration of the outcome for both the resource and diverse stakeholders (see definitions, for example, of mitigation and creative mitigation in NEPA Section 1508.20[c]-[e] and by the Advisory Council on Historic Preservation [ACHP] [2009a:28-29] and [2009b]). Creative mitigation augments standard mitigation and cannot be a stand-alone alternative for all mitigation. Many of the chapters in this special issue rely on standard mitigation practices to gain the data they may use in creative mitigation practice. While standard and creative mitigation may be different, they are not in opposition; rather, creative mitigation augments and complements the types of data collection that are often done through standard mitigation treatments.

\section{MITIGATION OF ADVERSE EFFECTS}

Although there numerous federal laws have been implemented over the years to protect cultural resources, it is NEPA and the NHPA, including Section 106, that have had the greatest impact on practice in the United States. Section 106 requires federal agencies, with jurisdiction over undertakings, to consider effects on NRHP-eligible and listed historic properties. For most agencies, there are multistep processes undertaken within Section 106. The ACHP recommends a four-step approach, all of which require consultation:

(1) Determine Applicability

(a) Is the Federal action an undertaking under 36 CFR Part 800 ?

(2) Determine Area of Potential Effects and Identify and Evaluate Resources

(a) Is there a potential for historic properties to exist in areas affected by the undertaking?

(b) If properties do exist, are they eligible or potentially eligible for the National Register?

(3) Determine Effects

(a) How will historic properties be affected?

(4) Resolve Adverse Effects

(a) Can adverse effects be avoided, minimized, or mitigated?

Under 36 CFR 800.5, archaeological sites may be "adversely affected" when unavoidable physical destruction or damage has the potential to impact NHPA-eligible or listed cultural resources. If the resource may be adversely affected, the agency proposing the undertaking must recommend mitigative measures to minimize the potential effects to the resource. There are several government and nongovernment organizations that provide resources and guidance on possible mitigative solutions, such as the ACHP (2009a, 2009b). Most of these guidance documents, however, recommend that recovery of "significant" information from these affected historic properties through excavation and other scientific means be the most appropriate preservation outcome. That said, ACHP (2009a:28-29) also recommends that alternatives to the traditional data recovery program be evaluated and implemented, if appropriate.

Typically, mitigation through a standard treatment of data recovery, analysis, report writing, and curation is deemed sufficient. Such approaches to the mitigation often result in a process in which the adverse effects are resolved in the most efficient way possible. As many scholars over the years have written, the Section 106 process is generally project driven, many times with a foregone conclusion that if this process is enacted, the project will proceed (e.g., Douglass et al. 2005:11; King 2002:46). One of the main issues with traditional interpretations of implementation of Section 106-data recovery through excavation - is that the results will many times not be meaningful to anyone other than archaeologists. In addition, data recovery may not take into account the desires and perspectives of all stakeholders.

If the outcome of ACHP's four-step approach results in identifying historic properties that will be adversely affected by an undertaking, data recovery, and related analysis, reporting and curation do not have to be the only resulting treatment. The outcomes of Section 106 should not be predetermined. Section 106 is a process that mandates the identification and the assessment of impacts, and the consideration of alternatives to avoid or reduce impacts to historic properties.

Although the main focus of this issue is on creative mitigation within the Section 106 process, two articles within this volume present creative mitigation measures from non-U.S. regulatory preservation perspectives-Albania and the pan-Mediterranean Basin. Although politically, geographically, and culturally distinct from the United States, these articles address similarly complex questions-that is, how can agencies and governments align the most appropriate mitigation practices to balance legal requirements, multiple stakeholder agendas, and the best outcomes for significant cultural resources? The authors in these two international perspectives study the different avenues for creative mitigation of adverse effects to cultural resources from the perspective of local regulations and local communities. Both articles argue that developing nations struggle with fundamental tasks such as the identification of what is significant and worthy of preservation. Like the contributors focusing on Section 106, these authors suggest that better historic preservation outcomes result from the often difficult task of balancing the interests of all stakeholders, including the tribal members, descendant communities, the public, researchers, and sensitive cultural resources.

\section{CREATIVE MITIGATION CONSIDERATIONS}

Creative mitigation is a process and outcome under Section 106 of the NHPA, as well as NEPA, which the ACHP (2009a:28-29; 2009b) encourages. Depending on the particular historic property and potential adverse effects to it, creative mitigation measures may lead to broader public involvement, increased appreciation of the past, and ultimately, to greater public pursuit of historic preservation (see Chandler 2009:121). As we discuss below, planning and implementation of creative mitigation measures need to ensure 
that the desired outcomes are meaningful to all involved. Efforts should be made to ensure the identification of all descendant communities and stakeholders, as at times this is not easily evident (e.g., Fuller 2011; McDavid and McGhee 2010; Singleton and Orser 2003). Public benefits, as well as the mitigation of adverse effects on historic properties, are essential components of any meaningful project, and these are best determined through thoughtful consultation. As Kurt E. Dongoske (2020) discusses in this special issue, the need for engaging consultation with all stakeholders by agencies is critical, in part because these groups may have fundamentally different viewpoints on resources and their meaning than CRM consultants and agencies.

When proposing the mitigation of adverse effects, the ACHP (2009a:27; see also 2009b) offers the following guidance for considering all stakeholder consultation on mitigation measures:

- What is the public interest?

- What are the benefits to, or concerns of, consulting parties, those they represent, and those who ascribe importance and value to the property?

- If the proposed mitigation is designed to advance our knowledge of the past, how will this knowledge be provided to the public and stakeholders?

- Will it enhance the preservation and management of listed or eligible archaeological sites in the region?

To us, a key benefit of creative mitigation is that it allows consideration of managing significant resources (historic properties in Section 106 terms) in a holistic_-rather than project-drivenfashion. When weighing treatment options, we can reflect on what may be best for the resource, in the context of all stakeholderincluding tribal members, descendant communities, and the public_-interests and concerns. A more meaningful and thoughtful mitigation process should become an integral part of historic preservation culture.

Applying a standard approach, such as fully documenting historic built environments (e.g., Historic American Building Survey/ Historic American Engineering Record [HABS/HAER]) or archaeological data recovery (Phase III Data Recovery), is often easier than considering alternative mitigation possibilities. Creative mitigation is a more engaged process built on an iterative and collaborative process that considers the balance between diverse viewpoints and objectives about what is best for a resource or group of resources. This process is likely to include considerations of mitigation measures that enhance public and technical knowledge, as well as protection of historic properties.

Another critical tool that may provide a better outcome is the use of agreement documents, both project specific and for land management purposes. Memorandum of agreements (MOAs) and programmatic agreements (PAs) are often legally required formal negotiations that are consulted on as part of federal projects. These types of formal agreement documents provide a platform for agencies to streamline the regulatory processes, and they can be used to develop nonstandard mitigation measures that offer the best outcomes for the long-term preservation of the resource.

At the end of the day, however, creative mitigation approaches should focus on the needs and desires of stakeholders as they relate to soon-to-be-impacted historic properties. In the case of tribes in the western United States, for example, the standard outcome of mitigation of adverse effects to historic resources through data recovery, analysis, report writing, and curation may not be of interest or resonate with them. The technical nature of mitigation reports may also not be accessible to tribal membersor to much of the public, generally-who do not have a background in archaeology. In addition, as Dongoske (2020) argues in this issue, many types of treatments may not resonate with tribal members because their views of the importance of archaeological sites may diverge from the views of archaeologists and agencies. For example, Dongoske argues that tribal members of Zuni Pueblo view all archaeological sites as TCPs, which are significant under multiple criteria for inclusion in the National Register of Historic Places. In this issue, the authors of the articles on mitigation in international contexts discuss developing nation-states in which the governments may hold new and varied concepts of what significant cultural resources are and how they should be treated.

\section{VALUES OF ARCHAEOLOGY AND ARCHAEOLOGICAL SIGNIFICANCE}

Mitigation of adverse effects is one of the last steps in many environmental regulatory procedures, including the Section 106 process. Tailoring those mitigation measures based on the varying characteristics of historic properties, rather than a one-size-fits-all approach, is an important avenue to consider. Although approaches to mitigation at times might ideally be predicated on a regional rather than a site-specific perspective, the reality is that mitigation is often site focused. This approach can and should be customized to specific historic properties and to all stakeholders so that it is accessible to them. Examples of regional and larger models for creative mitigation are taken up by several authors in this special issue, including those by Lynne Sebastian, Michael Heilen, and Sarah H. Schlanger and her colleagues, among others. A goal of engaging descendant communities and other stakeholders in the process and outcome of mitigation might be to lessen the loss of the impacted historic property (e.g., Nissley and King 2014:28-57).

Sebastian (2009) wrote about the topics of significance, information, and eligibility regarding what she believed the "framers" of the NHPA might have intended. To be eligible for the NRHP, and thus protected under U.S. historic preservation laws, archaeological sites must meet at least one of the four NRHP criteria (A through D) and possess integrity. To many, these criteria appear subjective. Sebastian, who is a contributor to this special issue, reminds us of the difficulty of the concept of "importance" under Criterion D (the principal criterion used for archaeological resources). Further bias may be introduced because the concept of importance is difficult to assess with archaeological inquiry, a field that is constantly changing and riddled with a myriad of competing theories and techniques. As she puts it, "There is no important or unimportant information in archaeology; there is just information" (2009:94), which, in turn, is information that is considered within the framework of where we are at any moment in time. She further argues that we should not think about archaeological sites simply in terms of eligibility for inclusion in the NRHP or solely based on their "importance." Instead, we ought to think 
about archaeological sites simply with respect to their significance and all that this means. Dongoske (2020), in this issue, further considers this point, arguing that tribal advisors might advocate for consideration of other criteria beyond criterion $D$, such as $A$ (for events) and B (for people).

Creative mitigation can help extend the concept of significance outside of traditional interpretations of Section 106 applications. We can ask: How can creative mitigation measures align with tribal and other stakeholder concepts of site significance? How can creative mitigation measures augment our knowledge of things related to the past, which may not be directly attainable through traditional data recovery mitigation? Creative mitigation measures make it possible to augment archaeological and historical information with additional lines of knowledge.

There is a wide range of possible alternatives to standard preservation mitigation —endless possibilities, really_and some important ones are highlighted in the articles in this special issue. We believe some useful avenues include focusing attention on specific sites over others; regional models in areas with little or no archaeological site information that might guide planning for future surveys/research; inclusion of cultural landscape perspectives; new histories, including indigenous perspectives, of areas or regions; preservation plans; preservation in place; mitigation banking; public education and outreach, including signage and museum exhibits; interpretive documents; the use of digital and other media technologies including films; and more (for expansion on these and additional examples, see ACHP 2009a:28-30; Fredine 2016; McManamon et al. 2016; Olson and Bailey 2019; Schlanger et al. 2013).

\section{ARTICLES IN THIS SPECIAL ISSUE}

The articles in this special issue offer insight into both the Section 106 mitigation process used in the United States and creative mitigation efforts in international contexts beyond U.S. federal historic preservation law. Lynne Sebastian (2020) is interested in how the Section 106 process can be enhanced through creative mitigation strategies to better consider the resource being mitigated in the broad sense. She wonders how we can, as historic preservation practitioners, expand the defining qualities of creative mitigation measures and programs to enhance the quality of standard mitigation approaches. Whether through thinking broadly about outcomes for resources in a region, including stakeholders earlier and more often in the process, or implementing mitigation measures that are meaningful to stakeholders, the contributors in this special issue offer a multitude of creative ideas that are more holistic in their approaches for mitigating adverse effects.

Kurt E. Dongoske, Tribal Historic Preservation Officer for Zuni Pueblo in New Mexico, shares his experience with Zuni perspectives on the traditional Section 106 mitigation process. He explores how working together with agencies in meaningful ways and developing creative mitigation can allow an outcome that is more meaningful to tribes. Dongoske argues that by focusing on the recovery of scientific information, CRM practitioners and agencies commonly use insensitive, invasive, and destructive measures to mitigate for adverse effects to sensitive archaeological resources. He laments that commensurate consideration is rarely accorded to the emotional, psychological, perspectival, and spiritual values that descendant Native American communities attribute to these places. Dongoske asserts that the associative relationships and integrity of traditional religious and cultural practices connected to cultural sites are always compromised because of methods used to determine significance. The lack of a balanced design of mitigation measures is often absent from accepted practice, resulting in the continual disenfranchisement of descendant Native American communities. His article shares how the Zuni worked with the Bureau of Reclamation to design a mitigative strategy that is meaningful and beneficial to their community. Dongoske emphasizes that only Zunis can define what appropriate mitigation is from an associative integrity perspective. He states that it is important that future mitigation development consider the associative values indigenous people ascribe to traditional cultural properties, which are often archaeological sites.

Stephen W. Tull (2020) focuses on creative mitigation measures as part of a Pennsylvania Department of Transportation expansion project, funded by the Federal Highway Administration of Interstate 95 (I-95) through the heart of Philadelphia. These agencies are undertaking a long-term, multiphase project to improve and rebuild this vital north-south Atlantic corridor through areas with a rich and intact history and prehistory. Given the complex urban setting, the archaeological subsurface testing for the I-95/Girard Avenue Interchange Improvement Corridor Project has been guided by a programmatic agreement. Through data recovery excavations, the contractor for the project, AECOM, has documented 30 historical period and Native American archaeological sites. Creative mitigation avenues for the project have focused on community engagement in a variety of ways, including the project's creation of its own professional journal, agency and public live interactive reporting, outreach programs, and a public archaeology center and curation facility. Overall, Tull's article presents an active and successful ongoing public program implementing the Section 106 process within the dense urban environment of Philadelphia, including both traditional mitigation measures and creative mitigation.

Lance K. Wollwage and his colleagues (2020) in the Washington State Historic Preservation Office (SHPO) offer insight into creative mitigation through the implementation of a statewide database. They note that data recovery is often the primary part of mitigation plans offered by federal agencies with undertakings that will destroy part or all of an archaeological site or historic building. They argue that by extracting important information before destruction, the public can recover some part of a historic resource's cultural valueits ability to help address important questions of science, engineering, and art. For more than 50 years, the product of mitigation efforts consisted of paper forms and reports kept by SHPOs and HABS/HAER documents filed with the Library of Congress. Identifying and accessing these records from the stacks, shelves, and filing cabinets of SHPO offices and information centers, they argue, requires considerable time and expense, even for experienced professionals. DAHP's response to these improvements in technology and approaches to communication over the last 20 years has been to create a web-based GIS system called the Washington Information System for Architectural and Archaeological Records Data (WISAARD). This statewide GIS relational database uses technology and information management systems to increase access to cultural resource information in ways that directly benefit the public, 
tribes, and scientific communities. Funding such programs may be a useful mitigation option for federal undertakings when data recovery is impossible or undesirable, and off-site solutions are needed to mitigate adverse effects.

Michael Heilen (2020) next studies the role of modeling in historic preservation and creative mitigation. In the roughly 50 years since the passage of the NHPA, he notes that over 56 million hectares of land have been surveyed in the United States, and nearly one million heritage resources have been identified and recorded. These efforts have correspondingly produced hundreds of thousands of project reports, vast collections of data, and a wealth of descriptive information about the past. Heilen argues that the accumulated data and information has the potential to help generate new scientific knowledge and management solutions. Using recent archaeological modeling projects as examples, Heilen shows the potential for compiling and synthesizing large environmental datasets within a GIS environment to model the nature and distribution of heritage resources. He argues that dedicated synthesis and modeling of data would allow the development of more effective and proactive research and management strategies, providing lasting benefit to diverse scientific and traditional communities and the public. As part of his larger view on modeling as an important resource to considering creative mitigation on projects, he discusses the obstacles to achieving successful synthesis and modeling efforts along with recommendations on how to develop and analyze appropriate datasets.

Jaime Almansa-Sánchez (2020) provides the preliminary results of his initiative, \#pubarchMED (Arqueología Pública en el Contexto Mediterráneo), which uses interviews of practitioners to understand the management of archaeological heritage within the 32 countries of the larger Mediterranean Basin from the perspective of comprehensive public archaeology. Almansa-Sánchez explores the possibilities for creative mitigation in these countries, whose country- and region-specific regulations are shaped by their political history and economic systems. Within many European countries, he notes, regulations require preventative measures to mitigate the impacts to cultural resources by, among other things, construction. His article, however, explores the wide range of interpretations and definitions of cultural resources and the varied regulations related to protecting cultural heritage. He further describes different regulations and the relationships between historic preservation and the larger societal values and constraints involved in the process, and he identifies this as the arena that most needs creativity within the mitigative process. Within the wide array of viewpoints on historic preservation in an extremely archaeologically rich region, he details and analyzes varied solutions to these problems. As part of his project, he considers how to implement creative mitigation within these diverse situations and how to identify, acknowledge, and incorporate diverse stakeholders in the process.

Lorenc Bejko (2020) examines recent trends in archaeological and historic preservation practices in Albania as the country's laws and economy have developed in the post-communist era. Bejko explores this with the goal of understanding Albania's past and the role this history plays in Albanian heritage practices today. $\mathrm{He}$ views Albania's approach as one of identity and nationalism within a context of nation-building as well as rapid expansion and transformations of both urban and rural landscapes within the small country. Bejko traces the evolution of archaeology and heritage legislation and practices in post-Communist Albania and the challenges in acknowledging multiple perspectives on historic preservation by different stakeholders. Within Albania, the standard mitigation process is commonly defined by either avoidance and/or a program of recovery/excavation and documentation, much to the consternation of diverse stakeholders for these resources. The author discusses the slow integration of creative mitigation as a logical alternative to traditional practices within Albanian historic preservation. In two case studies, Bejko demonstrates the successes and struggles of Albanian historic preservation regulations on large international projects and the way in which challenges were resolved by considering and implementing creative mitigation. He notes the potential to incorporate the lessons learned more completely as the Albanian system matures.

Back in the United States, Valerie J. McCormack and Kary Stackelbeck (2020) examine the creative mitigation process from initial conception to project completion for the mitigation associated with adverse effects from the drawdown of Lake Cumberland, Kentucky. In early 2007, signs of a dam failure triggered the U.S. Army Corps of Engineers (Corps) to implement an emergency drawdown of the lake. The emergency response prevented a lifesafety catastrophe, but the drawdown created a new erosion zone and exposed archaeological sites to looters. When it became clear that normal identification and evaluation processes were not an option, alternative and creative mitigation became a necessary approach for the Corps to meet its obligations under the NHPA. This article discusses the creative brainstorming between the Corps, the Kentucky State Historic Preservation Officer, and tribes that led to three alternative mitigation measures aimed at educational outreach, the raising of public awareness, and staff training. Furthermore, the authors identify challenges encountered during the implementation of the mitigation measures. Through the presentation of their mitigation journey, they share lessons learned to allow others considering alternative mitigation to be aware of execution challenges and successes.

Finally, Sarah H. Schlanger, Signa Larralde, and Martin (Chris) Stein (2020) discuss the successes of a BLM-implemented creative mitigation project. Implemented in 2008 to address impacts to the archaeological resources in the Permian Basin of southeastern New Mexico-now one of the nation's most active oil and gas energy fields - this creative mitigation program has supported more than $\$ 10$ million in field research programs, and it is poised to be able to fund about $\$ 1$ million in field research annually for the foreseeable future. The financial success of the program is mirrored by the program's outstanding contributions to the public's understanding of the Permian Basin's long and complex history of human occupation. The authors argue that, surprisingly, although other public lands are seeing similar rates of energy development, the critical elements of this program have not been picked up elsewhere in the BLM, and the program appears to be an example of a "one-off" alternative mitigation solution. The factors barring more widespread adoption include the ebb and flow of energy production activity, complications arising from mixed land status and the ability to work across jurisdictional boundaries, hesitation to change procedures that are working adequately, and a lack of capacity to institute systemic change. Nonetheless, the Permian Basin creative mitigation program, the 
authors argue, offers important considerations and insight for programs in other regions.

\section{CONCLUSIONS}

As has been argued many times, Section 106 and NEPA processes are generally viewed as compliance oriented and project driven.

They tend to be viewed as straightforward ways to ensure that the development project can go forward. In part, this is because there is a perception among CRM practitioners and agency regulators that this is the most efficient form of mitigation. Rarely are questions asked about alternative types and value-added approaches to complying with these regulations. As many of the authors in this special issue argue, these prescriptive approaches to mitigation disallow stakeholders-including tribal members, other descendant communities, and the public-to fully participate and work with agencies toward the preservation and treatment of sensitive cultural resources. Traditional approaches to mitigation may not allow these groups to share their viewpoints and to create solutions that are best for the resource and diverse stakeholders. Approaching creative mitigation measures through diverse lenses, rather than a strict focus on the compliance process, can lead to long-lasting importance placed on the outcomes. Some of these lenses may include those of diverse groups, the importance of place and history, and differing views on what is meant by preservation.

The path to incorporating creative mitigation within the normal suite of mitigation measures for adverse effects to historic properties will have bumps along the way, just as many standard practices do (see Sebastian 2004:13). Stakeholders-who may include tribal groups, descendant communities, and the public-will not likely be homogeneous in their thoughts on meaningful mitigation, and there may be disagreement on who project stakeholders are (Singleton and Orser 2003). In many parts of the United States, for example, there likely are multiple Indigenous groups who identify particular places as ancestral lands. It is likely that these stakeholders may have conflicting ideas on how archaeological sites in their ancestral lands should be, or even can be, mitigated for adverse effects (see Dongoske 2020). Solutions will take thoughtful consultation and planning to assure that the planned outcomes come to fruition. As is the case with standard mitigation plans, disagreements need to be resolved through honest and open outreach and consultation.

Lastly, it is a reality that agencies are not fully staffed to be able to undertake creative mitigation, let alone a full regulatory review of all projects, each and every time (e.g., King 2002:46). The key to determining which route is most beneficialstandard mitigation or creative mitigation-is identifying which projects, as well as stakeholders, can most benefit from each type of mitigation. CRM archaeologists, agency staff, and others need to work to balance different values that may be at odds with one another-such as time, cost, importance of resources, as benefits-in thinking about compliance trajectories (e.g., Bergman and Doershuk 2003:87). Although creative mitigation is not a panacea, we believe it is closer to the intent of cultivating meaningful collaboration with stakeholders and agencies during consultation. Creative mitigation is a "process" much like more standard ones, in that mitigation of adverse effects is the end result, but this alternative route-and the meaningful outcomes from consultation that may resultare key concerns (e.g., King 2002:30-33).

This issue of Advances in Archaeological Practice is intended to make it clear that creative mitigation measures can support both federal compliance with NEPA and Section 106 and international heritage management work. Mitigation that is creative and accountable means that the needs of individual resources will be better served and incorporated into the compliance process.

\section{Acknowledgments}

First and foremost, we thank the contributors to this special issue of the journal for their hard work conceptualizing and documenting different avenues toward creative mitigation. We hope that their broad perspectives on this theme will spur new interest and thinking on an important topic. This article and many others in this special issue originated in an organized symposium on creative mitigation held at the 2019 Society for American Archaeology (SAA) annual meeting in Albuquerque, New Mexico, and it was sponsored by the Arizona Army National Guard. We appreciate those contributors to the SAA symposium who could not participate here, as well as the conversations and discussions as part of that symposium that enhanced our discussion here. Several anonymous peer reviewers offered helpful ideas and critical feedback on this article. Time for organizing and editing this special issue of the journal, as well as making it open access, was made possible through funding by the Arizona Army National Guard to enhance public awareness of this important mitigation tool, for which we are grateful.

\section{Data Availability Statement}

There are no original data presented in this article.

\section{REFERENCES CITED}

ACHP (Advisory Council on Historic Preservation)

2009a Section 106 Archaeological Guidance. Electronic document, https:// www.achp.gov/sites/default/files/guidance/2017-02/ACHP\% 20ARCHAEOLOGY\%20GUIDANCE.pdf, accessed November 2, 2019

2009b Recommended Approach for Consultation on Recovery of Significant Information from Archeological Sites Synopsis. Electronic document, https://www.achp.gov/digital-library-section-106-landing/recommendedapproach-consultation-recovery-significant, accessed November 3, 2019.

Almansa-Sánchez, Jaime

2020 Spaces for Creativity in Mediterranean Archaeological Heritage Management. Advances in Archaeological Practice 8:275-287. DOI:10.1017/ aap.2020.21.

Bejko, Lorenc

2020 Emerging Needs for Creative Mitigation: Recent Trends in Archaeology and Historic Preservation in Albania. Advances in Archaeological Practice 8:288-298. DOI:10.1017/aap.2020.19.

Bergman, Christopher A., and John F. Doershuk

2003 Cultural Resource Management and the Business of Archaeology. In Ethical Issues in Archaeology, edited by Larry J. Zimmerman, Karen D. Vitelli, and Julie Hollowell-Zimmer, pp. 85-97. AltaMira Press, Walnut Creek, California.

Chandler, Susan

2009 Innovative Approaches to Mitigation. In Archaeology and Cultural Resource Management, edited by Lynne Sebastian and William D. Lipe, pp. 115-140. School for Advanced Research, Santa Fe, New Mexico. 
Dongoske, Kurt E.

2020 Making Mitigation Meaningful to Descendant Communities: An Example from Zuni. Advances in Archaeological Practice 8:225-235. DOI:10.1017/aap.2020.15

Douglass, John G., Cindi Alvitre, and Jeffrey H. Altschul

2005 The Politics of Archaeology: Diverse Concerns and Interests at the West Bluffs Project, Los Angeles, California. SAA Archaeological Record 5(2):1115.

Fredine, Jeff

2016 Addressing Cultural Landscapes in a Section 106 Context. In Highway Archaeology and Creative Mitigations: Celebrating 60 Years of CRM at NMDOT, edited by Cherie K. Walth, pp. 153-168. New Mexico Archaeological Council, Albuquerque.

Fuller, Reba

2011 Consultation in Cultural Resource Management: An Indigenous Perspective. In A Companion to Cultural Resource Management, edited by Thomas F. King, pp. 373-384. Wiley-Blackwell, Malden, Massachusetts.

Heilen, Michael

2020 The Role of Modeling and Synthesis in Creative Mitigation. Advances in Archaeological Practice 8:263-274. DOI:10.1017/aap.2020.23.

King, Thomas F.

2002 Thinking about Cultural Resource Management: Essays from the Edge. AltaMira Press, Walnut Creek, California.

2013 Cultural Resource Laws and Practice. AltaMira Press, Walnut Creek, California.

McCormack, Valerie J., and Kary Stackelbeck

2020 Alternative Mitigation to Counter Resource Losses from the Lake Cumberland Drawdown, Kentucky. Advances in Archaeological Practice 8:299-306. DOI:10.1017/aap.2020.24.

McDavid, Carol, and Fred McGhee

2010 Commentary: Cultural Resource Management, Public Archaeology, and Advocacy. In Handbook of Postcolonial Archaeology, edited by Jane Lydon and Uzma Z. Rizvi, pp. 481-494. Routledge, New York.

McManamon, Francis P., John Doershuk, William D. Lipe, Tom McCulloch, Christopher Polglase, Sarah Schlanger, Lynne Sebastian, and Lynne Sullivan

2016 Values-Based Management of Archaeological Resources at a Landscape Level. Advances in Archaeological Practice 4:132-148.

Nissley, Claudia, and Thomas F. King

2014 Consultation and Cultural Heritage. Left Coast Press, Walnut Creek, California.

NPS (National Park Service)

2019 National Historic Preservation Act. Electronic document, https://www. nps.gov/subjects/historicpreservation/national-historic-preservation-act. htm, accessed November 3, 2019.

O'Brien, Michael J., R. Lee Lyman, and Michael B. Schiffer

2005 Archaeology as a Process: Processualism and Its Progeny. University of Utah Press, Salt Lake City.

Olson, Heather L., and Ralph Bailey

2019 Collaborative Mitigation: Creative Success Stories Using Archaeological
Collections. In Using and Curating Archaeological Collections, edited by S. Terry Childs and Mark S. Warner, pp. 53-63. SAA Press, Washington, DC. Praetzellis, Mary, and Adrian Praetzellis

2011 Cultural Resource Management Archaeology and Heritage Values. Historical Archaeology 45(1):86-100.

Raab, L. Mark, Timothy C. Klinger, Michael B. Schiffer, and Albert C. Goodyear 1980 Clients, Contracts, and Profits: Conflicts in Public Archaeology. American Anthropologist 82:539-551.

Schlanger, Sarah H., Signa Larralde, and Martin Stein

2020 Long-Term Prospects for Landscape Mitigation Programs. Advances in Archaeological Practice 8:307-312. DOI:10.1017/aap.2020.20.

Schlanger, Sarah H., George MacDonell, Signa Larralde, and Martin Stein

2013 Going Big: The Permian Basin Memorandum of Agreement as a Fundamental Shift in Section 106 Compliance. Advances in Archaeological Practice 1:13-23.

Sebastian, Lynne

2004 Archaeology and the Law. In Legal Perspectives on Cultural Resources, edited by Jennifer R. Richman and Marion P. Forsyth, pp. 3-16. AltaMira Press, Walnut Creek, California.

2009 Deciding What Matters: Archaeology, Eligibility, and Significance. In Archaeology and Cultural Resource Management, edited by Lynne Sebastian and William D. Lipe, pp. 91-114. School for Advanced Research, Santa Fe, New Mexico

2020 What Makes Some Mitigation Measures and Programs "Creative"? (And Where Does That Leave the Rest of Them?). Advances in Archaeological Practice 8:220-224. DOI:10.1017/aap.2020.5

Singleton, Theresa A., and Charles E. Orser

2003 Descendant Communities: Linking People in the Present to the Past. In Ethical Issues in Archaeology, edited by Larry J. Zimmerman, Karen D. Vitelli, and Julie Hollowell-Zimmer, pp. 143-151. AltaMira Press, Walnut Creek, California.

Tull, Stephen W.

2020 Sustainable Neighborhood Public Outreach: I-95 GIR Archaeological Investigations in Philadelphia. Advances in Archaeological Practice 8:236252. DOI:10.1017/aap.2020.17.

Wollwage, Lance K., Allyson Brooks, Rob Smith, Morgan McLemore, Annie Strader, and Kim Gant

2020 Beyond Data Recovery: Developing Cultural Information Systems in the Online Era. Advances in Archaeological Practice 8:253-262. DOI:10.1017/ aap.2020.13.

\section{AUTHOR INFORMATION}

John G. Douglass $\square$ Statistical Research Inc., 3170 E. Fort Lowell, Tucson, AZ 85716, USA; School of Anthropology, University of Arizona, Tucson, AZ 85721 USA (jdouglass@sricrm.com, corresponding author)

Shelby A. Manney $\square$ Arizona Army National Guard, NGAZ-FMO-EM, 5636 E. McDowell Rd. M5330, Phoenix, AZ 85008-3495, USA 